\title{
Mexico-Olive Oil: Remedy without a cause?
}

\author{
CHAD P. BOWN * \\ Department of Economics and International Business School, Brandeis University, Waltham, MA, USA \\ NIALL MEAGHER * * \\ Advisory Centre on WTO Law
}

\begin{abstract}
This paper provides a legal-economic analysis of the unappealed WTO Panel Report in Mexico-Olive Oil. The case involved a countervailing-duty measure imposed by Mexico on imports of olive oil from the European Communities (in particular, Spain and Italy). The dispute raised important issues regarding the determination of causation of injury, as neither the Panel nor the investigating authority gave much credence to evidence that the main complaint of the domestic industry was the loss of a distribution agreement and brand-name rights with a Spanish exporter. The dispute also raised interesting concerns regarding the remedies for violations of procedural obligations in the conduct of anti-dumping/ countervailing-duty investigations and the right of a domestic producer that has ceased production to seek protection under the trade-remedy laws.
\end{abstract}

\section{Introduction}

Approximately half of the jurisprudence of the WTO dispute-settlement system consists of disputes arising out of trade-remedy or contingent-protection measures imposed by WTO Members. Given this fact, it might be expected that the jurisprudence on the WTO Anti-Dumping and Subsidy and Countervailing Measure (SCM) Agreements would be relatively settled. Not so. Each new WTO dispute under these agreements, including the recent unappealed WTO Panel Report in Mexico-Olive Oil, throws up both new issues that have yet to be resolved and recurring issues where the jurisprudence continues to evolve.

While the Mexico-Olive Oil dispute was neither particularly complicated nor very controversial, the decision raised several issues that gave rise to new

\footnotetext{
* Email: cbown@brandeis.edu

**Email: Niall.Meagher@acwl.ch

The authors thank our discussant, Kamal Saggi, as well as Thomas Prusa, Meredith Crowley, Petros Mavroidis, Jorge Huerta Goldman, and the participants at the ALI Review of WTO Case Law 2008 Conference in Geneva for helpful comments. Shranutha Reddy provided outstanding research assistance. All remaining errors are our own.
} 
interpretations of the relevant agreements or that illustrated some of the recurring problems in challenging anti-dumping or countervailing-duty measures in WTO dispute-settlement proceedings. First, we analyse as potentially problematic the manner in which the Panel addressed the question of whether Mexico sufficiently ruled out 'any known factors' aside from the impact of the subsidy on the injury suffered by its domestic olive-oil growing industry. Second, we describe the quandary of how to implement findings of procedural violations associated with the SCM and Anti-Dumping Agreements. Finally, we discuss some examples of important 'non-issues' that arose in the dispute. In particular, we point out how an issue such as 'pass-through' - one that has proven to be quite divisive in earlier WTO jurisprudence on subsidies and countervailing measures - was not controversial in this dispute given the context of the market and policies at issue in the case.

The rest of this paper proceeds as follows. In Section 2, we introduce the legal facts of the dispute as well as political-economic history of events surrounding the WTO case. Section 3 describes the legal findings of the WTO Panel Report, and Section 4 provides our legal-economic analysis of the dispute. Finally, Section 5 concludes.

\section{Background}

In this section of the paper, we first establish the legal and factual background of the case before turning to the underlying political-economy 'facts' to understand better the market environment and incentives at stake in the both the underlying Mexican countervailing-duty (CVD) investigation and the subsequent WTO dispute-settlement proceedings.

\subsection{Legal and factual background}

This dispute arose out of a CVD measure imposed by Mexico on imports of olive oil from the European Communities (EC). The matter began in March 2003, when a Mexican company, Fortuny, submitted an application to the Mexican investigating authority, Economía, for the imposition of CVDs on imports of olive oil from the EC. The application alleged that during the period April-December 2002, subsidized imports of olive oil from the EC materially retarded the establishment of an olive-oil industry in Mexico. Economía published a notice of initiation of the investigation on 16 July 2003. A preliminary resolution imposing provisional CVDs was published on 10 June 2004. A final resolution imposing definitive CVDs was published on 1 August 2005 - almost 25 months after the investigation was initiated. The EC requested consultations under the WTO Understanding on Rules and Procedures Governing the Settlement of Disputes (the DSU) on 31 March 2006 and requested the establishment of a Panel on 7 December 2006. The Panel's Report was circulated to the membership of the WTO on 4 September 2008 - in less time (21 months), ironically, 
Table 1. Mexico's 2001 tariff rates on imports of olive-oil products, in percent

\begin{tabular}{lccccc}
\hline \hline & \multicolumn{5}{c}{ Harmonized system product at the 8-digit level } \\
\cline { 2 - 6 } Tariff category & 15091001 & 15091099 & 15099001 & 15099002 & 15099099 \\
\hline MFN bound rate & 45.0 & 45.0 & 45.0 & 45.0 & 45.0 \\
MFN applied rate & 10.0 & 10.0 & 20.0 & 20.0 & 20.0 \\
Preferential rates: & & & & & \\
NAFTA countries (US, Canada) & 0.0 & 0.0 & 0.0 & 0.0 & 0.0 \\
Chile, Costa Rica, Uruguay & 0.0 & 0.0 & 0.0 & 0.0 & 0.0 \\
Colombia, Venezuela & 2.8 & 2.8 & 5.7 & 5.7 & 5.7 \\
Nicaragua & 7.0 & 7.0 & 14.0 & 14.0 & 14.0 \\
El Salvador, Guatemala, Honduras & 8.8 & 8.8 & 17.5 & 17.5 & 17.5 \\
European Community & 9.0 & 9.0 & 18.0 & 18.0 & 18.0 \\
& & & & & \\
\hline \hline
\end{tabular}

Source: Data collected by authors from the WTO's Integrated Database via WITS. The MFN applied tariff rates are the same as the 2001 rates reported in the table for years 1999-2003.

than Economía took to complete the investigation. The Panel Report was not appealed.

There was little dispute in either the investigation or the WTO dispute that the EC had in fact provided the subsidies in question. The EC had, after all, notified the measures at issue as subsidies to the WTO. Instead, the investigation and, later, the WTO dispute, turned on other issues, including the following two questions in particular: (i) as the EC paid the subsidy to the olive growers, rather than the olive-oil producers, whether Economía could treat the subsidy as having been provided to the olive-oil exports without conducting a 'pass-through' analysis, and (ii) whether the fact that the Mexican producer had ceased production affected either the producer's standing to seek relief or the injury analysis. While the facts are not fully clear, it appears that the Mexican producer, Fortuny, may have ceased production after it lost the right to use a Spanish brand name, Ybarra, to market its domestically produced olive oil in the Mexican market. As we will discuss, the commercial relevance of the loss of the right to this brand name is a key issue in the economic analysis of the case.

\subsection{The trade, policies, political-economy facts, and background of the case}

Before turning to a discussion of the legal findings in the dispute and our legaleconomic analysis, we first establish a basic understanding of the political economy of the markets and policies involved in the case. Understanding these features is critical to help inform our later analysis and choice of how to model the issues that arise.

First, as Table 1 indicates, Mexico's WTO tariff binding during this time for the olive-oil imports involved in the dispute was $45 \%$, and its MFN applied tariff rate 
Figure 1. Mexico’s imports of olive oil by foreign source, 1996-2007

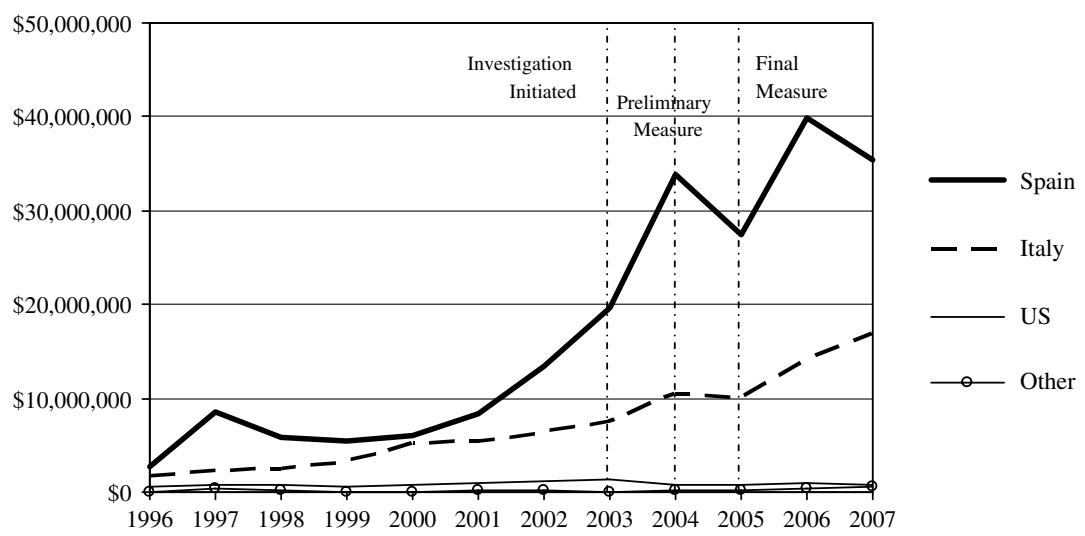

Source: Data collected by authors. Mexico's imports under HS (1996) categories 150910 (Virgin olive oil) and 150990 (Other olive oil), data taken from the UN Comtrade via WITS.

during this time period ranged from $10 \%$ to $20 \%$, depending on the olive-oil sub-product. According to its tariff schedule, Mexico apparently offered many different preferential rates to different trading partners. These included free trade in olive-oil products to its trade-agreement partners under NAFTA, as well as separate arrangements with Chile, Costa Rica, and Uruguay. Interestingly, and notwithstanding the countervailing-duty order, even the EC received a small Mexican tariff preference in these products below Mexico's MFN applied rate.

As Figure 1 illustrates, the deep tariff preferences that Mexico offered to other countries (listed in Table 1) beyond what it granted to exporters from the EC apparently had very little effect on Mexico's import sourcing during this time period. More than $90 \%$ of Mexican imports of these olive-oil products derived from Spain or Italy alone. The only other single foreign source with more than $1 \%$ of Mexico's olive-oil imports during this time period was the United States, and the level of the value of US exports to Mexico during this time period is relatively flat at roughly $\$ 1$ million per year. ${ }^{1}$

As Figure 1 also documents, the value of the combined EC exports to Mexico at stake is relatively small. We understand that this is much less than the value of the trade at stake in a number of other WTO disputes, including several initiated by the EC on behalf of its exporters' foreign-market-access interests, which frequently run into the hundreds of millions and even billions of dollars worth of annual exports. Before the initiation of the countervailing-duty investigation in 2003,

1 Since the value of Mexico's olive-oil imports from the US during this time period is relatively constant at roughly $\$ 1$ million per year, in the face of growing Mexican imports from the EC the US share of the Mexican import market steadily declined from a high of $11.4 \%$ in 1996 to $1.6 \%$ in 2007 . 
Figure 2. The importance of the Mexican market to Spain's and Italy's olive-oil exporters, 1996-2007

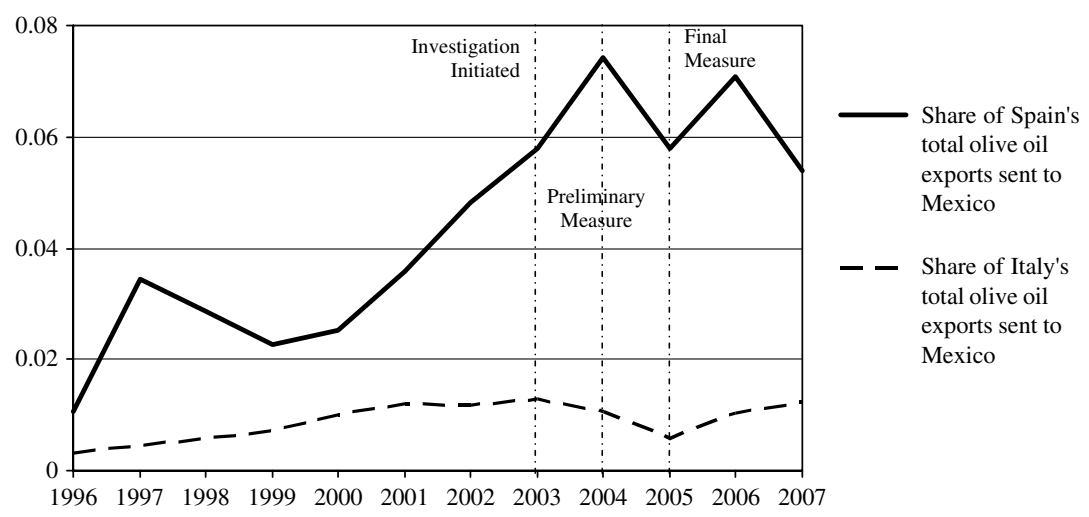

Source: Data collected by authors. Spain and Italy exports under HS (1996) categories 150910 (Virgin olive oil) and 150990 (other olive oil), data taken from the UN Comtrade via WITS. Exports are 'extra-EC-15' for all years in the sample.

Mexican combined imports from Spain and Italy had never been more than $\$ 30$ million per year. Nevertheless, as Figure 1 also illustrates, Mexico was a growth market for Spanish and Italian exporters of olive oil. Even after the initiation of the CVD investigation in 2003 and the imposition of the preliminary CVD in 2004, Spain (and to a lesser extent Italy) continued to expand its exports to Mexico. There was slight growth between 2004 and 2007, with combined Spanish and Italian sales of over \$50 million in both 2006 and 2007, even after imposition of the final CVD order. As we describe in more detail below, the Spanish firm Ybarra's 2002 decision to halt its brand-licensing arrangement with (what would become) the Mexican olive-oil firm Fortuny is consistent with what is suggested by a simple analysis of the time path of the trade data; i.e., that the Spanish firm may have ended the licensing arrangement in which it sourced olive oil locally (from growers and processors within Mexico) in order to switch to supplying the Mexican market under the Ybarra brand with an increase in exports of olive oil from Spain. Indeed, the Panel noted that the loss of this arrangement led to a decline in Fortuny's sales to the Ybarra distribution network in 2001-2002. ${ }^{2}$

While Spanish and Italian olive-oil exports to Mexico during this time period are relatively small in dollar terms (Figure 1), as Figure 2 indicates, Mexico has become an increasingly important export market for Spanish olive-oil producers, comprising $5-7 \%$ of its total (extra-EC) olive-oil exports during 2003-2007,

2 Panel Report, Mexico-Definitive Countervailing Measures on Olive Oil from the European Communities (Panel Report hereinafter), at para. 7.315. 
compared to a 2-4\% share during 1996-2001. While not pictured, the dominant export market for Spanish firms is the United States $23-28 \%$ of total extra-EC exports). Other important markets include Japan, Australia, and to a lesser extent Brazil and Korea. The Mexican market is relatively less important for Italian oliveoil exporters, as also indicated by Figure 2, as it accounts for only roughly $1 \%$ of Italy's total (extra-EC) olive-oil exports. The most important export markets for Italy for olive oil are the United States (55-60\% of total extra-EC exports), Japan, Australia, and Canada. ${ }^{3}$

The EC's subsidy programme for olive oil was originally established pursuant to Regulation No. $136 / 66$ of September 1966, which was subsequently modified to regulate further the modalities for and amount of the olive-oil subsidy. Economía cited Regulation No. 1638/98 (20 July 1998), Regulation No. 1794/ 2002 (9 October 2002), and Regulation 1221/2003 (8 July 2003) as the other EC measures by which the subsidy was provided during the period under investigation. Economía found that pursuant to these measures, subsidies were provided to olive-oil growers based on the subsequent quantity of olive oil actually produced. At the EC level, the maximal per-unit subsidy was based on an overall community-wide production quota that was then divided among the five olivegrowing EC states (France, Greece, Italy, Portugal, and Spain). Spain, Italy, and Greece received the vast majority of the quota. If any of these states exceeded their production quota, the per-kilogram amount of the subsidy was reduced proportionately based on the amount by which actual production in each country exceeded the quota. In the year 2001/2002, the subsidies to producers in Spain and Italy amounted to $€ 0.64 / \mathrm{kg}$ and $€ 1.01 / \mathrm{kg}$ respectively. ${ }^{4}$ The regulations governing the subsidy contained no conditions as to whether the olive oil was to be sold in domestic or export markets.

\footnotetext{
3 Given that the United States is such an important export market for both Spanish and Italian olive-oil producers, it is worth investigating whether the EC's primary political-economy motive in filing a WTO dispute against Mexico is concern that Mexican development of a domestic olive-oil-producing industry might lead to a formidable competitor entering the more important US market. One potential reason for such a concern would be if Mexican olive-oil firms were advantaged relative to EC firms in the US market through a substantial tariff preference granted under NAFTA. According to the WTO's Integrated Database (obtained via WITS), this motive can be ruled out as the size of the US tariff preference to Mexico granted under NAFTA is only 5 cents per kilogram of olive oil (vis-à-vis the US MFN applied rate to which EC firms are subject), which is extremely small given the world price of olive oil.

4 See Economía's Resolución final de la investigación por subvención de precios sobre las importaciones de aceite de oliva virgen, originarias de la Unión Europea (Comunidad Europea), principalmente del Reino de España y la República Italiana, independientemente del país de procedencia, 1 August 2005, para. 22.89. Using Spain as an example, the amount of the subsidy was derived as follows: Spain's national production quota was 760,027 tons, while actual production was 1,562,531 tons. The normal subsidy for production that came in at or under the national quota level was $€ 1.3225 / \mathrm{kg}$. The actual per-unit subsidy was calculated by multiplying the normal subsidy by the ratio of the quota level to actual production: $€ 1.3225 / \mathrm{kg} \times(760,027 / 1,562,531)=€ 0.64 / \mathrm{kg}$.
} 


\section{Discussion of legal findings}

In this section, we discuss the WTO Panel's findings on the claims brought by the EC challenging Economía's final determination to impose countervailing duties.

\section{1 'Peace Clause' claims}

The EC challenged several aspects of Economía's investigation and determination. While most of the EC's claims arose under the SCM Agreement and Article VI of the General Agreement on Tariffs and Trade 1994 (the 'GATT 1994'), the EC also claimed that Mexico had failed to exercise 'due restraint' in initiating a CVD investigation under Article 13(b)(i) of the WTO Agreement on Agriculture - the so-called 'Peace Clause'. Since the Peace Clause applied only during the period of implementation of the Agreement on Agriculture, which expired at the latest in 2004 , this issue is now largely of historical interest and merits only brief discussion. The Panel began by holding that because Article 13 of the Agreement on Agriculture was in force on the date on which Economía initiated the investigation, it applied to Economía's initiation of the investigation. The Panel also noted, however, that because Economía conducted the investigation as if Article 13 applied, it would proceed on the same basis. ${ }^{5}$

The EC's first claim was that Economía acted inconsistently with Article 13(b)(i) of the Agreement on Agriculture by accepting an application for an investigation on the basis of an allegation of material retardation of a domestic industry, rather than on the basis of an allegation of 'injury' as expressly referred to in Article 13(b)(i). The Panel rejected this claim, noting that 'injury' is defined in footnote 45 of the SCM Agreement to include 'material retardation'. ${ }^{6}$ The Panel also noted that, in fact, Economía had initiated the investigation on the basis of injury, in this broader sense, and imposed both the provisional and definitive duties on the basis of 'material injury' rather than 'material retardation'.'

Next, the EC argued that Mexico acted inconsistently with Article 13(b)(i) of the Agreement on Agriculture by failing to show 'due restraint' in initiating the investigation. The Panel interpreted 'due restraint' to refer to a 'proper, regular, and reasonable demonstration of self-control, caution, prudence and reserve'. 8 The Panel then rejected all three grounds on which the EC alleged that Economía had failed to exercise due restraint. First, the Panel found that a failure to hold consultations with the EC prior to initiating the investigation was not a lack of due restraint. Second, the Panel rejected the claim that Economía did not spend enough effort investigating the issue of whether there were domestic producers other than Fortuny before initiating the investigation, noting that Economía had conducted a four-month investigative process on this issue before initiating the investigation.

\footnotetext{
5 Panel Report, paras. 7.54, 7.59.

6 Ibid., para. 7.61 .

7 Ibid., para. 7.63 .

8 Ibid., para. 7.67.
} 
Finally, the Panel rejected the EC's claim that Economía failed to show due restraint by allegedly converting an application based on an allegation of 'material retardation' into an investigation of 'material injury'. In conclusion, the Panel noted that Economía appeared to have 'proceeded with prudence and caution, indicating self-restraint rather than a lack thereof'. ${ }^{9}$

\subsection{Initiation of the investigation}

The EC's next set of claims related to the initiation of the investigation. The EC claimed that Economía acted inconsistently with Article 13.1 of the SCM Agreement by failing to invite the EC for consultations, or by failing to provide an appropriate time interval for consultations to take place, prior to the initiation of the investigation. Article 13.1 provides that 'as soon as possible after an application [for a CVD investigation] is accepted, and in any event before the initiation of any investigation, the [exporting] Members ... shall be invited for consultations with the aim of clarifying the situation ...' (emphasis added). The EC argued that the investigation was 'initiated' on 2 July 2003, the date on which the Minister signed the initiation resolution, while Mexico argued that the initiation took place on 16 July 2003, the date on which the resolution was published in Mexico's Official Journal. Since Mexico invited the EC for consultations on 4 July 2003 and the consultations took place on 17 July, the Panel had to resolve the issue of when the investigation was 'initiated' for the purposes of the SCM Agreement.

The Panel noted that resolution of this issue involved questions of both law and fact: the legal question of what constituted 'initiation' within the meaning of the SCM Agreement and the factual question of when this 'initiation' took place in the Mexican investigation. With respect to the former question, the Panel noted that footnote 37 of the SCM Agreement defines 'initiated' to mean the 'action by which a Member formally commences an investigation'. ${ }^{10}$ The Panel considered that this definition left it up to Members to determine the date on which it would 'formally commence' investigations and, therefore, that what constitutes 'initiation' may vary based on the procedural rules in each Member's CVD law. ${ }^{11}$ Examining Mexican law, the Panel concluded that, as a factual matter, the date of initiation under Mexican law was the date on which the notice takes legal effect, which is the day after the date of publication in the Official Journal, not the date on which the Minister signed the resolution. ${ }^{12}$ Accordingly, the Panel rejected the EC's claim that the invitation for consultations was made only after the initiation of the investigation.

The Panel also rejected the EC's claim that Mexico acted inconsistently with Article 13.1 by failing to hold consultations, or to provide sufficient time for

9 Ibid., para. 7.80 .

10 Ibid., para. 7.24 .

11 Ibid., paras. 7.27-7.28.

12 Ibid., para. 7.30 . 
consultations to take place, before the initiation of the investigation. The Panel interpreted the obligation in Article 13.1 as being limited to an obligation to invite the responding Member for consultations and did not imply an obligation to bold consultations before initiating the investigation. ${ }^{13}$

\subsection{Procedural claims regarding the conduct of the investigation}

The EC made three claims regarding the conduct of the investigation by Economía. First, the EC claimed that the investigation took too long: Mexico acted inconsistently with Article 11.11 of the SCM Agreement by failing to complete the investigation within one year and in no case more than 18 months after the date of initiation. As noted above, the investigation took more than 24 months from the date of initiation (17 July 2003) to the date of the final resolution (1 August 2005). The Panel found that Article 11.11 imposes a clear and unequivocal rule that no investigation may exceed 18 months and, therefore, that Mexico had acted inconsistently with Article 11.11. ${ }^{14}$

Second, the EC claimed that Mexico acted inconsistently with Article 12.8 of the SCM Agreement by failing to provide the interested Members and parties with the 'essential facts under consideration which form the basis for the decision whether to apply definitive measures'. Mexico argued that the preliminary resolution constituted the disclosure of the essential facts on which the final decision was to be made. The EC responded that a preliminary resolution was not a suitable vehicle to disclose 'essential facts' because company-specific information could not be provided in a public resolution and, in any event, additional 'essential facts' could come to light in further investigations following the preliminary determination. The Panel interpreted the term 'essential facts' to refer to 'the specific facts that underlie the investigating authority's final findings and conclusions in respect of the three essential elements - subsidization, injury and causation - that must be present for application of definitive measures'. ${ }^{15}$ The preliminary resolution could serve to disclose these facts only if new 'essential facts' were not incorporated into the record following the issuance of the preliminary resolution. In this case, the Panel found that Economía did not appear to rely in the final determination on any facts that had not been disclosed in the preliminary resolution. ${ }^{16}$ Moreover, the EC failed to establish that it was denied an opportunity to defend its interests following the publication of the preliminary resolution. ${ }^{17}$ Accordingly, the Panel found that the EC had failed to establish that Mexico had acted inconsistently with Article 12.8 .

Finally, the EC argued that Mexico acted inconsistently with Article 12.4.1 of the SCM Agreement by failing to require interested parties to provide

13 Ibid., para. 7.35 .

14 Ibid., paras. 7.120-7.123.

15 Ibid., para. 7.110.

16 Ibid., para. 7.115.

17 Ibid., paras. 7.112-7.113. 
nonconfidential summaries of confidential information. The Panel noted that merely providing a public version of a confidential document, from which the confidential information has been deleted, may not be sufficient to satisfy Article 12.4.1, because the public version may not 'permit a reasonable understanding of the substance of the information submitted in confidence' within the meaning of Article 12.4.1. ${ }^{18}$ The Panel also noted that a statement of reasons why summarization of the information is not permitted may be provided only in 'exceptional circumstances'. ${ }^{19}$ The Panel disagreed with the reasoning of the Panel in Mexico-Steel Pipes and Tubes with respect to the corresponding obligation in Article 6.5.1 of the Anti-Dumping Agreement that the investigating authority was not required to examine the reasons why summarization of the confidential information would not be possible. ${ }^{20}$ However, the Panel agreed with the Mexico-Steel Pipes and Tubes Panel that merely providing access to the confidential version of the document constituted an alternative to compliance with the requirements of Article 12.4.1 of the SCM Agreement (and Article 6.5 of the AntiDumping Agreement) regarding the provision of public summaries of confidential information.

Turning to the case before it, the Panel found that while Economía required public versions of confidential documents, it did not require summarization of the confidential information and it was not possible to obtain a reasonable understanding of the deleted information from the public versions. ${ }^{21}$ In addition, while some parties asserted in general statements that summarization was not possible because of exceptional circumstances, these statements were unsupported assertions. Economía could not have assessed, therefore, whether such 'exceptional circumstances' existed. ${ }^{22}$ Accordingly, the Panel concluded that Mexico acted inconsistently with its obligations under Article 12.4 .1 by failing to require nonconfidential summaries of confidential information or a statement of why, due to exceptional circumstances, such summarization was not possible.

\section{4 'Pass-through' of subsidy benefits}

The first substantive issue addressed by the Panel was the EC's claim that Mexico acted inconsistently with Articles 1 and 14 of the SCM Agreement by failing to calculate properly the benefit conferred on the recipient of the subsidies at issue pursuant to Article 1.1 of the SCM Agreement and by failing to explain adequately its calculation pursuant to Article 14 of the SCM Agreement. The EC argued that Mexico should have conducted a 'pass-through' analysis to determine the extent to which any benefits received from the subsidies by olive growers were passed through to exporters of olive oil to Mexico. The EC argued that the olives were an

18 Ibid., paras. $7.87-7.88$.

19 Ibid., paras. 7.89-7.90.

20 Ibid., para. 7.92 .

21 Ibid., paras. 7.96-7.98.

22 Ibid., paras. 7.99-7.101. 
input into the product actually exported and subject to the investigation and that the exporters of olive oil were not related to the olive growers, who actually received the subsidies at issue. ${ }^{23}$ Mexico argued that the subsidies at issue were direct subsidies on the production of olive oil and had been notified as such to the WTO. Accordingly, no pass-through analysis was required. ${ }^{24}$

As the Panel noted at the start of its analysis, there has been considerable discussion of 'pass-through' issues in WTO law. ${ }^{25}$ The Panel noted that in USSoftwood Lumber IV, the Appellate Body found that where a subsidy is conferred on the production of an input product used to produce the imported product under investigation, and the producer of the input product is unrelated to the producer of the importer product, a pass-through analysis must be conducted to determine the extent to which the subsidy on the input product was transferred to the imported product. This is necessary to ensure that the amount of any CVD imposed is not in excess of the amount of the subsidy on the imported product in accordance with GATT Article VI:3. ${ }^{26}$ The Panel noted the pass-through analysis is required only where the producer of the input product and the producer of the imported product are not related.$^{27}$ Also, a pass-through analysis is not necessary where both the input product and the finished product fall within the definition of the product under investigation. ${ }^{28}$ Finally, the Panel noted that the extensive jurisprudence on whether benefits from nonrecurring subsidies continued to exist and could be deemed to be transferred to a producer's new owners following the privatization of state-owned producers was not relevant to the case at hand. ${ }^{29}$

The Panel began its analysis of the EC's pass-through claims by noting that while the previous jurisprudence found the legal basis for the obligation to conduct a pass-through analysis in GATT Article VI:3, the EC did not bring a claim under that Article and, instead, based its pass-through claims on Articles 1 and 14 of the SCM Agreement. ${ }^{30}$ The Panel understood the EC's claim with respect to Article 1 of the SCM Agreement to be that the failure to conduct a pass-through analysis was inconsistent with the aspect of the definition of a subsidy under Article 1.1(b) that ' $a$ benefit is thereby conferred'. ${ }^{31}$ The Panel also noted that, in response to questioning, the EC had suggested that the obligation to conduct a pass-through analysis was 'implicit' in Articles 1 and $14 .^{32}$

The Panel found that Article 1.1(b) contains a definition of the term 'subsidy'. Thus, the provision addresses only the question of whether a benefit existed and,

23 Ibid., para. 7.125 .

24 Ibid., para. 7.128.

25 Ibid., para. 7.130 et seq.

26 Ibid., para. 7.139, citing Appellate Body Report, US-Softwood Lumber IV, paras. 140-147.

27 Panel Report, para. 7.140.

28 Ibid., para. 7.143.

29 Ibid., para. 7.141.

30 Ibid., para. 7.145 .

31 Ibid., para. 7.147.

32 Ibid., para. 7.148. 
therefore, whether or not there was a subsidy. ${ }^{33}$ However, the Panel found, Article 1.1(b) does not establish a requirement to calculate precisely the amount of any benefit accruing. ${ }^{34}$ The Panel's total separation of the question of the existence of a subsidy and the amount of the subsidy is a little discordant, especially in light of the de minimis provision of Article 11.9 of the SCM Agreement, under which CVD investigations must be terminated when the amount of a subsidy is de minimis (less than $1 \%$ ). It should be noted, however, that the EC expressly told the Panel that its argument was not that a benefit was not provided or that a subsidy did not exist, but simply that Economía had failed to determine the amount of the subsidy under Article 1.1. ${ }^{35}$ Since the Panel concluded that Article 1.1 does not impose a requirement to determine the amount of the benefit, it concluded that Mexico did not act inconsistently with that provision by failing to conduct a pass-through analysis.

With respect to the EC's pass-through claim under Article 14 of the SCM Agreement, the Panel understood the EC's claim to be that because Economía failed to conduct a pass-through analysis where one was required, its explanation of how it calculated the amount of subsidization was not reasoned and adequate and, therefore, inconsistent with Article $14 .^{36}$ Article 14 provides, inter alia, that the method used to calculate the benefit 'shall be transparent and adequately explained'. The Panel saw nothing in this language to suggest that Economía was required to conduct a pass-through analysis or that the failure to do so meant that Economía's analysis was not transparent or adequately explained. ${ }^{37}$ To the contrary, the Panel failed to see 'how the Final Resolution either lacks transparency as to the method used to calculate the benefit to the recipient or fails to adequately explain that method'. ${ }^{38}$

The Panel went on to conclude that even if Article 14 could be construed to contain an obligation to conduct a pass-through analysis, it would find no basis to conclude that Economía had acted inconsistently with that obligation. ${ }^{39}$ In the Panel's view, the evidence supported Economía's view that the subsidy in question consisted of aid to olive growers for the production of olive oil. ${ }^{40}$ Thus, the olive grower received aid only to the extent that it could prove that it has converted olives into olive oil and was paid only on the basis of actual kilograms of olive oil produced. ${ }^{41}$ In other words, the subsidy was not a subsidy for an input product (olives) that may have been passed through to the imported product (olive oil) but

\footnotetext{
33 Ibid., para. 7.151.

34 Ibid., para. 7.152.

35 Ibid., para. 7.150.

36 Ibid., para. 7.154.

37 Ibid., para. 7.159 et seq.

38 Ibid., para. 7.168.

39 Ibid.

40 Ibid.

41 Ibid.
} 
was a subsidy provided for the production of the imported product (olive oil) itself. ${ }^{42}$ Accordingly, the Panel found that the EC had failed to establish that Mexico acted inconsistently with Article 14 of the SCM Agreement by failing to conduct a pass-through analysis.

In addition to the pass-through claims, the EC also made three additional claims with respect to how Economía calculated the benefit under Article 14 of the SCM Agreement. The EC argued that (i) Economía failed to adjust its calculation for a portion of the EC's olive-oil exports that were not subject to the subsidy; (ii) Economía failed to make adjustments for certain costs incurred by exporting companies; and (iii) Economía's calculation of the subsidy margin was inflated because Economía compared the amount of the subsidy with the exporter's sales prices at the ex-factory level rather than at the CIF level. The Panel rejected all of these claims. ${ }^{43}$

\subsection{Definition of 'domestic industry'}

The EC claimed that the applicant, Fortuny, did not produce the like product either at the time of the application or during the period of the injury investigation. Consequently, Mexico acted inconsistently with Article 16 of the SCM Agreement by initiating the investigation on the basis that Fortuny's application was made 'by or on behalf of the domestic industry' within the meaning of that Article.

The Panel noted that the definition of the domestic industry in Article 16.1 of the SCM Agreement refers to 'producers'. The Panel then found that to 'produce' refers to the nature of the activity of bringing something into existence. ${ }^{44}$ The Panel noted that the precise issue of whether a company that did not actually produce at a given time could be considered as a producer, and hence part of the 'domestic industry' for the purposes of Article 16 had not previously been addressed in the jurisprudence. ${ }^{45}$ However, the Panel endorsed the approach taken in the US-Lamb dispute of focusing on the essential nature of the business activities of a given enterprise as determinative of whether the enterprise could be included in the domestic industry for the product. ${ }^{46}$ Based on this approach, the Panel found no basis to exclude from the domestic industry companies whose essential nature included production of the like product but who simply did not do so at a given point in time. ${ }^{47}$

42 Ibid.

43 Ibid., paras. 7.170-7.176.

44 Ibid., para. 7.192.

45 Ibid., para. 7.193.

46 Ibid., para. 7.196. The issue in US-Lamb was whether enterprises that did not actually produce the like product itself (i.e., growers of live lambs) could be considered as producers of the like product (i.e., processed lamb meat). The Panel and the Appellate Body concluded that because the lamb growers did not themselves process lamb meat, they could not be considered as part of the domestic industry producing lamb meat. Ibid., para. 7.195.

47 Ibid., para. 7.196. 
The Panel found contextual support for its interpretation in several other provisions of the SCM Agreement, including Article 15.2, which provides that a determination of the volume and effects of subsidized imports on domestic prices for the like product can be made by reference to either 'production' or 'consumption'. The Panel interpreted this reference to consumption to mean that an injury determination could properly be made even in the absence of actual production at a given time. ${ }^{48}$ The Panel also noted that the list of injury factors to be considered under Article 15.4 of the SCM Agreement reflected a 'multifaceted approach' to determining the condition of the enterprises involved and that actual and potential declines in output constituted only one element of this analysis. In these circumstances, the Panel considered that actual output at a given point in time was not necessarily to fall within the definition of a producer of the like product. ${ }^{49}$ The Panel also observed that there may be several commonplace reasons why producers might routinely not produce at a given point in time, including seasonality, technology innovations, distribution cycles, and force majeure. ${ }^{\mathbf{5 0}}$

Finally, the Panel turned to the object and purpose of the countervail provisions of the SCM Agreement. Since the object and purpose was to provide for the application of trade remedies in circumstances where subsidized imports cause material injury or a threat thereof, or material retardation, of a domestic industry, it would make no sense to exclude companies that were not actually producing at a given point in time from those remedies. ${ }^{51}$ Otherwise, an industry that was 'so badly injured as to be forced to cease production for some period ... would be disqualified from obtaining the very remedy aimed at addressing such injury'. ${ }^{2}$ Accordingly, the Panel found that Article 16.1 does not require that an enterprise or group of enterprises seeking CVD relief must actually produce the like product, either around the date of filing of their application or during the injury period of investigation, in order to be considered 'producers' and, therefore, part of the 'domestic industry' within the meaning of Article 16.1.53

The Panel then turned to the question of whether Fortuny was a 'producer' of the like product. The Panel noted that Economía relied on extensive factual information in determining that Fortuny was a 'producer' of olive oil, including its (and its predecessor's) history of production, monthly business data for three previous years, information regarding the state of its facilities, and its business plan to resume production. Economía also conducted verification at Fortuny's premises, which established that production actually resumed after the preliminary resolution. Economía also tested the viability of Fortuny's business plan. ${ }^{54}$ Based

48 Ibid., para. 7.198.

49 Ibid., paras. 7.200-7.201.

50 Ibid., para. 7.202.

51 Ibid.

52 Ibid., para. 7.203.

53 Ibid., para. 7.204.

54 Ibid., paras. 7.209-7.212. 
on these facts, the Panel concluded that Economía made a reasoned and adequate determination, supported by positive evidence, that Fortuny was in fact a producer of the like product. ${ }^{55}$ Accordingly, the Panel rejected the EC's claims that Mexico improperly treated Fortuny as a producer and, consequently, improperly treated Fortuny as part of the domestic industry within the meaning of Article 16.1 of the SCM Agreement.

The EC also claimed that Economía failed to examine adequately whether there were producers of olive oil other than Fortuny and whether there was sufficient support for the application among the domestic industry within the meaning of Article 11.4 of the SCM Agreement. The Panel rejected this claim, noting that Article 11.4 did not preclude the investigating authority from making this determination solely on the basis of information provided by the applicant. ${ }^{56}$ In the Panel's view, whether the investigating authority needs further information to make this determination must be decided on a case-by-case basis. ${ }^{57}$

In the present case, the Panel found that Economía reviewed detailed evidence, from both Fortuny and other sources, as to whether there were other producers of olive oil, and concluded there was no evidence before Economía of the existence of any other producers. ${ }^{58}$ Accordingly, the Panel rejected the EC's claim that Mexico acted inconsistently with Article 11.4 of the SCM Agreement in determining whether there was support for the application.

The Panel also rejected a claim by the EC under Article 16.1 of the SCM Agreement and Article VI:6(a) of the GATT 1994 that Economía failed to determine properly whether Fortuny constituted the entire domestic industry. Again, the Panel rejected this claim, setting out over the course of three pages of its report the steps taken and evidence assembled by Economía as to the possible existence of other producers. ${ }^{59}$ The Panel also noted that no other companies came forward during the course of the investigation. ${ }^{\mathbf{6 0}}$

\subsection{Claims relating to the injury analysis}

The EC's final set of claims related to Economía's injury analysis. First, the EC argued that it was not clear whether Economía's final determination was one of material retardation or material injury and that it would be inconsistent with Article VI:6 to make simultaneous findings of both. The Panel rejected this claim, finding as a matter of fact that Economía made a finding of material injury, not material retardation, in both its preliminary and final resolutions. ${ }^{61}$

55 Ibid., para. 7.214.

56 Ibid., para. 7.225.

57 Ibid., para. 7.228 .

58 Ibid., paras. 7.230-7.237.

59 Ibid., para. 7.245 .

60 Ibid., para. 7.247.

61 Ibid., para. 7.279. 
Next, the EC claimed that Economía's injury analysis was inconsistent with Article 15.4 because Economía used data from nine-month periods in each year of the injury period of investigation (April-December 2000, 2001, and 2002), rather than full-year data for those years, as the basis of its injury determination. Citing the Panel Report in Mexico-Steel Tubes and Pipes, the Panel noted that the use of partial-year periods could be accepted only if the investigating authority could explain how developments within the partial period were reflective of the period as a whole and whether the partial periods were justified and not anomalous in the particular case. ${ }^{62}$ The Panel rejected Mexico's explanations that the use of the ninemonth periods may avoid distortions in the data and found that Mexico had acted inconsistently with Article 15.4 of the SCM Agreement in using these partial periods. ${ }^{63}$ Based on this finding, the Panel decided to exercise judicial economy with respect to the EC's other claims under Articles 15.1 and 15.4, including the claims that Economía acted inconsistently with Article 15.1(a) by basing its analysis of the volume and price effects of the subsidized imports on data from Fortuny's business plan rather than 'actual' price data for part of the period of investigation. ${ }^{64}$

The EC also argued that Economía did not properly examine any known factors other than the subsidized imports that may have caused injury to the domestic industry within the meaning of Article 15.5 of the SCM Agreement. The EC referred to six other factors in particular, including inter alia, Fortuny's loss of its distribution network, its loss of the right to use a Spanish brand name (Ybarra), and its high costs. ${ }^{65}$ The Panel interpreted the obligation to examine other known factors in Article 15.5 as consisting of two parts. First, the investigating authority is required to consider other factors known to it either as a result of its own investigation or because they were raised by the interested parties. Second, the investigating authority is required to analyse each of those factors separately and to explain the nature and extent of the injurious effects of these other factors, separating and distinguishing them from the injurious effects of the subsidized imports. ${ }^{66}$ Because the Panel found that Economía had addressed each of the six factors identified by the EC in its preliminary and final resolutions, concluding that none of them caused injury to the domestic industry, the Panel focused its analysis on the adequacy of Economía's analysis.

The Panel conducted a detailed review of Economía's analysis of each of the factors referred to by the EC. ${ }^{67}$ Based on this analysis, the Panel concluded that Economía had not 'dismiss[ed] these factors with qualitative assertions. Rather, it carefully examined, separated and distinguished the effects of each factor from the

62 Ibid., para. 7.286 .

63 Ibid., para. 7.290 .

64 Ibid., paras. 7.252, 7.291.

65 Ibid., para. 7.294 .

66 Ibid., para. 7.305 .

67 Ibid., paras. 7.309-7.316. 
effects of the subsidized imports, and reasonably concluded that these factors were not contributing to the injury suffered by Fortuny. ${ }^{, 68}$ The Panel also found that while there might be factual circumstances in which it would be necessary to examine the collective impact of the other known factors, it was not necessary in this case, where Economía reasonably concluded that none of the other factors caused injury. ${ }^{69}$ Accordingly, the Panel found that the EC had failed to establish that Mexico had acted inconsistently with Article 15.5 of the SCM Agreement.

\subsection{Summary of the Panel's findings}

To summarize, the Panel rejected most of the EC's claims, finding that Mexico acted inconsistently only with: (i) Article 11.11 of the SCM Agreement, by failing to conclude the investigation within 18 months; (ii) Article 12.4.1, by failing to require nonconfidential summaries of confidential information or an explanation of the reasons why summarization was not possible; and (iii) Article 15.1, by limiting the injury analysis to nine-month periods in each year of the injury period of investigation. ${ }^{70}$ The Panel rejected the rest of the EC's claims and, not surprisingly, declined to make a suggestion, pursuant to the second sentence of Article 19.1 of the DSU, that repeal of the measure would be the most appropriate means of bringing the measure into conformity with Mexico's obligations.

This may not seem like a very successful outcome for the EC. Nevertheless, at the DSB meeting of 11 December 2008, Mexico notified the DSB that it had withdrawn the measure effective 18 November 2008. However, it is not clear that Mexico's withdrawal of the measure was directly in response to the Panel Report or the nature of the Panel's rulings and recommendations - Mexico's statement to the DSB referred to a domestic-court decision ordering Economía to terminate the measure.

\section{Legal-economic analysis}

In this section, we discuss in more detail the following issues raised by the WTO Panel Report in this case: (i) Economía's and the Panel's analysis of 'any [other] known factors' in the causation analysis under Article 15.5 of the SCM Agreement, including both the legal standard of review applicable to the Panel's analysis and the economic issues arising out of the analysis; and (ii) the nature of Members' obligations to implement rulings and recommendations regarding 'procedural' violations of WTO contingent-protection laws, including, in this case, the time limit on the completion of an investigation under Article 11.11 of the SCM Agreement. We will also discuss briefly some other issues arising out of the

68 Ibid., para. 7.317.

69 Ibid., para. 7.318 .

70 Ibid., para. 8.1. 
case, including the pass-through issue and the Panel's reliance on Fortuny's business plan as evidence of injury.

\subsection{Injury by subsidy and Mexican examination of 'any known factors'}

\subsubsection{Legal aspects of the findings on 'any known factors': standard of review}

Before discussing the economic aspects of the case, a brief discussion of the legal aspects of the Panel's findings on 'any known factors' under Article 15.5 of the SCM Agreement is merited. At the beginning of its Report, the Panel discussed at length the standard of review it was required to apply to Economía's determination. The Panel noted the Appellate Body's statement that a Panel's role was to 'inquire whether the evidence and explanation relied on by the investigation authority reasonably supports [the investigating authority's] conclusions'. ${ }^{71}$ The Panel also quoted at length from the Appellate Body Report in US-Softwood Lumber VI (Article 21.5-Canada), in which the Appellate Body stated, inter alia, that:

The panel must examine whether the explanations provided demonstrate that the investigating authority took proper account of the complexities of the data before it, and that it explained why it rejected or discounted alternative explanations and interpretations of the record evidence. A panel must be open to the possibility that the explanations given by the authority are not reasoned or adequate in the light of other plausible alternative explanations, and must take care not to assume itself the role of initial trier of facts, nor to be passive by 'simply accept [ing] the conclusions of the competent authorities'. ${ }^{72}$

At the outset of its analysis of the Article 15.5 claims, the Panel quoted the Appellate Body's statement in US-Hot-Rolled Steel that this analysis (actually, its analog in the Anti-Dumping Agreement) required that:

Investigating authorities must make an appropriate assessment of the injury caused to the domestic industry by other known factors, and they must separate and distinguish the injurious effects of the dumped imports from the injurious effects of those other factors. This requires a satisfactory explanation of the nature and extent of the injurious effects of the other factors, as distinguished from the injurious effects of the dumped imports. ${ }^{73}$

Like all attempts to articulate precise standards by which tribunals must review determinations of lower authorities, this standard of review is problematic. The line between making a careful examination of whether the investigating authority did its job properly, on the one hand, and not becoming a de novo trier of the facts,

71 Ibid., para. 7.3, quoting Appellate Body Report, US-Countervailing Duty Investigation on DRAMS, para. 187.

72 Appellate Body Report, US-Softwood Lumber VI (Article 21.5-Canada), para. 93, quoting Appellate Body Report, US-Lamb, para. 106.

73 Panel Report, para. 7.301, quoting Appellate Body Report, US-Hot-Rolled Steel, para. 226. 
on the other hand, is very fine. It is particularly problematic with respect to the review of determinations such as material injury and causation determinations, where there are standards as to how the investigating authority is to make its determination but no objective definitions of what constitutes sufficient injury or causal link. These problems are clearly displayed in this Panel Report.

In its review of Economía's 'any known factors' analysis, the Panel stated that it would first factually analyse Economía's causation analysis and then consider whether it was consistent with Article 15.5. ${ }^{74}$ The Panel went on to recite, in some detail, how Economía addressed each of the other factors at issue. It must be acknowledged that Economía's analysis was more detailed than is often the case. However, the second part of the Panel's analysis is less clear. After reciting how Economía analysed each factor, the Panel either offered no review of Economía's analysis $^{75}$ or, at the end of its recapitulation of the analysis, merely asserted that Economía "reasonably found" 76 that the factor was not a cause of injury to Fortuny. In a brief conclusory paragraph, the Panel stated that Economía 'carefully examined, separated, and distinguished the effects of each factor from the effects of the subsidized imports, and reasonably concluded that these factors were not contributing to the injury suffered by Fortuny'. ${ }^{77}$ Since the Panel merely summarized Economía's analysis, however, it is difficult to discern how or where the Panel determined that Economía's analysis and conclusions were 'reasonable'.

The systemic concern here is that Panels might perceive any independent review of the evidence on their part as involving them impermissibly as de novo triers of fact, with the danger that the obligation on the investigating authority would be reduced simply to an obligation to provide a lengthy explanation of its determination. The obligation may become an obligation to provide a 'reasoned' determination rather than a 'reasonable' one. As noted, this concern is more acute with respect to inherently subjective determinations such as those of injury and causation, where reviewing Panels are likely to be especially careful to avoid a de novo review. For the purpose of the present paper, we draw attention to this issue simply to illustrate why Panels tend to avoid the sort of analysis contained in the following subsections.

\subsubsection{Economic purpose of CVD provisions of the SCM Agreement}

In order to make a legal-economic assessment of the Panel's logic and decisions, it is necessary to understand the main objective of the SCM Agreement that allows importing countries to respond with countervailing duties when a trading partner imposes subsidies that affect exported products. We follow the logic, coherently presented in Grossman and Mavroidis (2003) as well as many other contributions

\footnotetext{
74 Panel Report, para. 7.308.

75 Ibid., paras. $7.311,7.312,7.315$, and 7.316 .

76 Ibid., paras. $7.313,7.314$.

77 Ibid., para. 7.317.
} 
to the ALI series, that the objective of the SCM Agreement is to discourage subsidies that harm the import-competing interests of domestic producers. ${ }^{78} \mathrm{We}$ follow the specific approach of Grossman and Mavroidis (2003: 186) who state 'Articles 14 and 19 [of the SCM Agreement] require the size of the countervailing duty to be set so as to just offset the adverse effects of the subsidy on conditions in the domestic industry. This latter provision can only be understood as an attempt to restore competitive conditions in the industry to what they would have been had the subsidy been absent.'

From this perspective, one fundamental question in this dispute is whether the 'benefit' to EC exporters of olive oil had an effect on the conditions of competition between EC firms and domestic Mexican producers of olive oil. Essentially, the issue is whether the Mexican firms were injured by the benefit conferred to the subsidy-receiving EC firms. We examine this possibility within the context of a more formal economic model that we present below.

However, before turning to the analysis, it is necessary to identify the second important issue highlighted by Grossman and Mavroidis; i.e., that the relevant counterfactual to examine is the 'competitive conditions in the industry ... had the subsidy been absent'. More concretely, in particular, Article 15.5 of the SCM Agreement states that in a CVD investigation ' $\mathrm{t}$ ] he authorities shall also examine any known factors other than the subsidized imports which at the same time are injuring the domestic industry, and the injuries caused by these other factors must not be attributed to the subsidized imports'. In this particular dispute, the Panel was satisfied that Mexico had met the burden of examining 'any known factors' that might be the alternative cause of injury to the domestic olive-oil industry. Our analysis is not as charitable, as the simple economic model that we analyse below suggests a number of important questions that the Panel might have more fully addressed.

Consider Figure 3, which presents a simple illustrative model describing the Mexican and EC market for olive oil that is broadly consistent with the underlying events at issue in this case. We assume there are two countries (the EC and Mexico) that trade only this one good under competitive conditions that we model with simple linear supply and demand curves. The three panels combine to illustrate: Figure 3(a) the Mexican domestic market for olive oil, Figure 3(c) the EC's domestic market for olive oil, and Figure 3(b) the 'international' market for olive oil in which the countries' import demand and export supply curves determine the equilibrium level of international trade. From Figure 3(a), it is apparent that Mexico is a relatively costly supplier of olive oil $\left(S_{M E X}^{0}\right)$. Thus, for a range of world prices that are sufficiently low, the difference between Mexico's domestic demand for olive oil $\left(D_{M E X}^{0}\right)$ and its domestic supply will be given by its import demand curve for olive oil, given by $M D_{M E X}^{0}$, in Figure 3(b). On the other hand, Figure 3(c)

78 See, for example, Grossman and Mavroidis (2005a), Grossman and Mavroidis (2005b), and Horn and Mavroidis (2006). 
Figure 3. The initial equilibrium and olive-oil trade before the 'shocks'

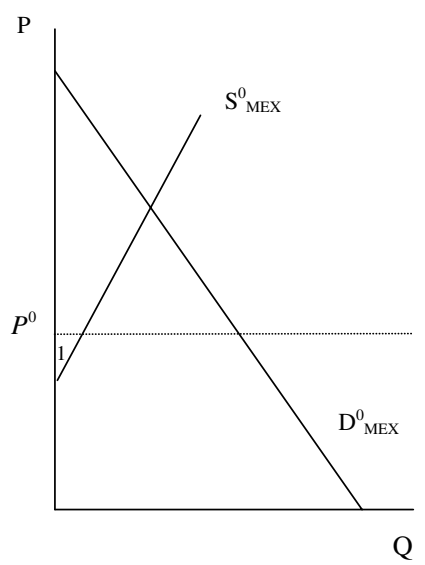

(a) Mexico

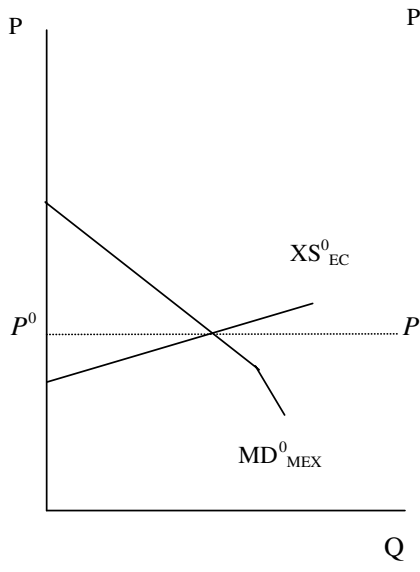

(b) International market

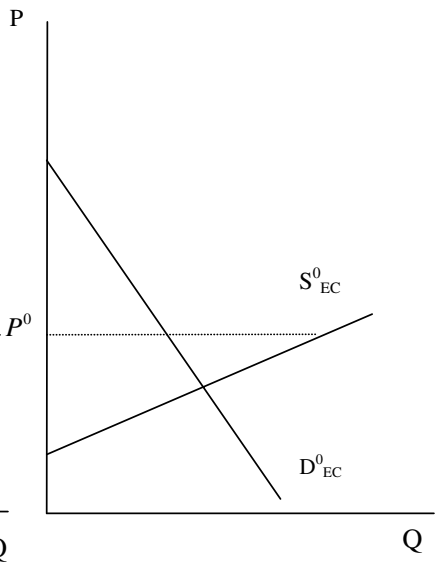

(c) $\mathrm{EC}$

illustrates the EC as apparently a lower-cost supplier of olive oil $\left(S_{E C}^{0}\right)$. Thus, at relatively low world prices, the difference between the EC's domestic demand for olive oil $\left(D_{E C}^{0}\right)$ and its domestic supply will be given by its export supply curve for olive oil, given by $X S_{E C}^{0}$, in Figure 3(b).

We begin with an initial equilibrium outcome of liberal trade and before the occurrence of any shocks that we will introduce momentarily. ${ }^{79}$ The intersection of the Mexican import demand and EC export supply curves in Figure 3(b) determines the initial equilibrium price, $P^{0}$, and at this world price the EC exports olive oil to Mexico. At this initial equilibrium price, Mexico has a small domestic industry whose level of production is given by the intersection of the price, $P^{0}$, with its domestic supply curve, $S_{M E X}^{0}$. The Mexican industry's economic welfare under this initial outcome, which will be the benchmark by which we measure 'injury' in the analysis that follows, is given by the triangular area ' 1 ' in Figure 3(a).

The information presented in the Panel Report identifies at least two potentially important 'shocks' to the determinants of supply and demand in this economic system that could substantially disturb the equilibrium in a way that causes injury to the Mexican industry. We will present an analysis of each in turn. The first 'shock' is the subsidy granted to EC producers of olive oil. The second 'shock' is the severance of a relationship between the Mexican firm Fortuny and the Spanish firm Ybarra in 2002, which prevented Fortuny (the legal Mexican business successor in 2002 to the former firm Formex-Ybarra) from carrying the Ybarra brand or of having access to the Ybarra distribution network within Mexico.

79 The analysis would not materially change if we were to start from an initial equilibrium in which Mexico imposed a small tariff on EC exporters of olive oil, as was the case in this dispute. 
Figure 4. The isolated effect of a production subsidy to EC olive-oil producers

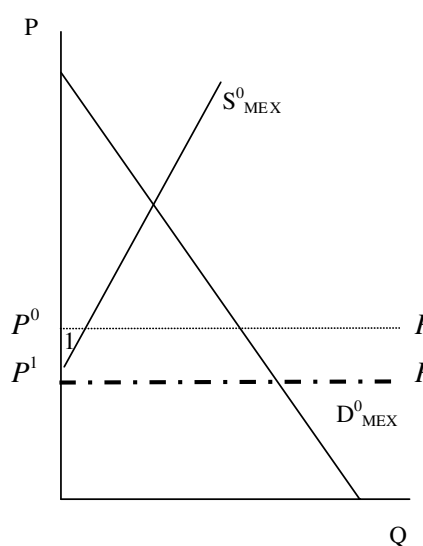

(a) Mexico

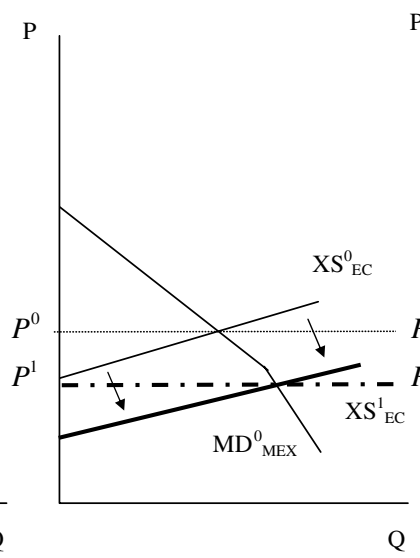

(b) International market

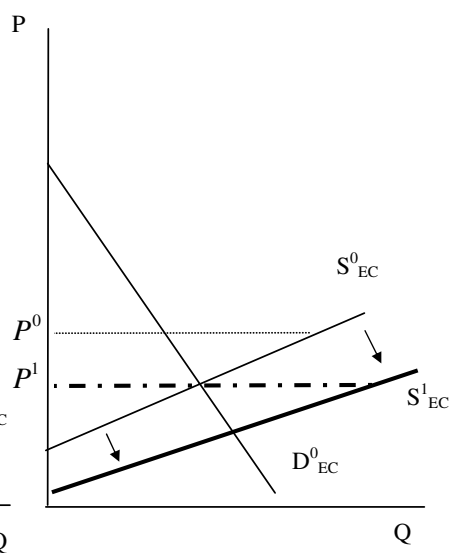

(c) EC

\subsubsection{The isolated effect of an EC olive-oil-production subsidy on the market}

In Figure 4, we first examine the implications of a production subsidy to the EC firms that produce olive oil. As we argue elsewhere in more detail, we find little to suggest that the subsidies were not received by olive-oil-producing firms and that they were not also contingent on their level of production. The effect of such a subsidy can be analysed by tracing through the impact beginning in Figure 4(c). A production subsidy to the EC industry lowers the marginal cost to producing each additional unit of olive oil and is represented by an outward shift in the EC's domestic supply curve from $S_{E C}^{0}$ to $S_{E C}^{1}$. Because the domestic supply curve has changed, for any given price, the EC's industry's willingness to export (i.e., the difference between the domestic supply curve and the domestic demand curve) also changes. Thus, in Figure 4(b), the EC's export supply curve shifts in response to the domestic subsidy from $X_{E C}^{0}$ to $X S_{E C}^{1}$. The intersection of Mexico's (unchanged) import demand curve $M D_{M E X}^{0}$ with the new EC export supply curve $X S_{E C}^{1}$ occurs at a slightly lower equilibrium price, $P^{1}$. As is consistent with the facts of this case, the new price $P^{1}$ is lower than the point at which the Mexican industry's supply curve intersects the price axis; i.e., the lowest price it is willing to receive to produce a positive level of output before shutting down.

If this were the only 'shock' taking place in this market during this time period, the analysis would be very straightforward. Since the EC subsidy reduces the equilibrium price of olive oil, it is the cause of injury to the Mexican olive-oil industry, which would be represented in Figure 4(a) as the loss of producer surplus associated with the initial price $P^{0}$, given by the area ' 1 '. However, as we illustrate next, there is reason to suspect that this was not the only 'shock' taking place 
Figure 5. The isolated effect of the loss of the Ybarra brand and distribution network to Mexican olive-oil producers

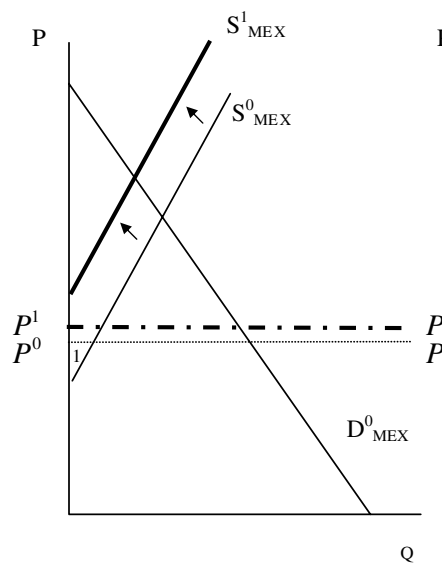

(a) Mexico

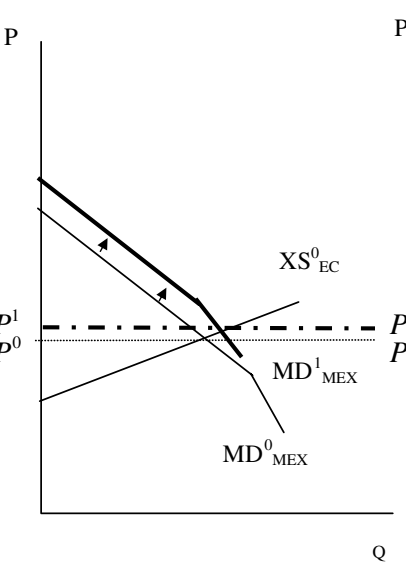

(b) International market

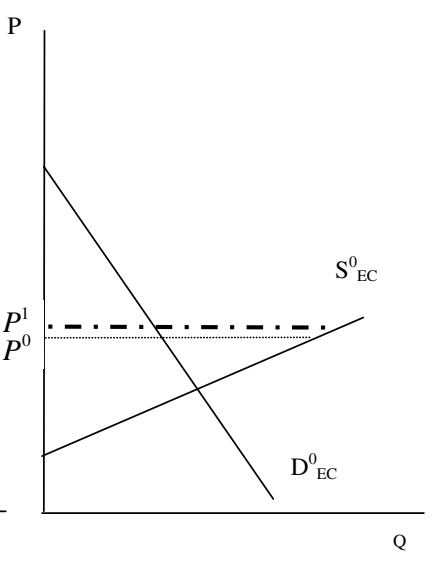

(c) EC

during this time period. This complicates the issue of causation in the injurydetermination analysis.

\subsubsection{The isolated effect of the loss of the Ybarra brand and distribution network to Mexican olive-oil producers}

We next examine the potential implications of the severance of a relationship between the Mexican firm Fortuny and the foreign firm Ybarra in 2002, which meant that Fortuny could no longer carry the Ybarra brand or have access to the Ybarra distribution network in Mexico. Begin again with the initial equilibrium outcome described in Figure 3, which is the benchmark illustrated in Figure 5. The need for Fortuny to create a new distribution network and to do new marketing to establish its new brand after 2002 suggests a sudden increase in its costs, which is represented on the figure as an inward shift in the Mexican supply curve from $S_{M E X}^{0}$ to $S_{M E X}^{1}$; i.e., the marginal cost to Fortuny to produce the same quantity of olive oil has increased. ${ }^{80}$

Since Mexico's import demand curve is determined by the difference between its domestic demand and domestic supply, an inward shift of the domestic supply

80 An alternative to modeling this as a negative cost shock facing the Mexican industry would be to model it as a negative demand shock. For example, if the loss of the Ybarra brand caused Mexican consumers to switch their demand for olive oil away from Mexican-produced olive oil toward an alternative product, this would cause the domestic demand curve $\left(D_{M E X}^{0}\right)$ in Figure 5(a) to shift in. While not pictured in Figure 5, this would cause Mexico's import demand schedule $\left(M D_{M E X}^{0}\right)$ to shift in, resulting in a lower equilibrium price of olive oil. This would also lead to injury to the Mexican olive-oil producers through a loss of producer surplus (area ' 1 '). 
curve (Figure 5(a)) corresponds with an outward shift of Mexico's import demand curve from $M D_{M E X}^{0}$ to $M D_{M E X}^{1}$ in Figure 5(b). The new, post-'shock' equilibrium price for olives is at $P^{1}$. As we have illustrated it, so as to be consistent with one possible interpretation of the economic facts of the case, this slightly higher price of olive oil in this instance is too low for the Mexican domestic industry to produce any olive oil (Figure 5(a)) under its new cost structure reflecting both its 'old costs' plus the new expenditures necessary for distribution and marketing. Thus, we have documented one situation in which it is possible that the negative shock to Fortuny of the additional costs to branding/distribution associated with the severed relationship with Ybarra is itself a sufficient cause of injury to the firm to cause the firm to shut down (produce zero units of olive oil domestically).

Indeed, the injury suffered by the domestic industry in both Figure 4 (the EC subsidy) and Figure 5 (the severance of the Ybarra relationship) of these scenarios is the same. In both 'pre-shock' scenarios, the industry received a producer surplus of area ' 1 '. In both 'post-shock' scenarios, the Mexican firms shut down, so its producer surplus is zero. Thus, the two instances have an identical loss of producer surplus.

The Panel accepted Mexico's argument that Economía had examined the brand and distribution network issues as potential 'factors' and properly ruled them out as causes of injury to Fortuny. In the case of the brand issue, the Panel accepted Economía's reasoning that 'other unknown brands had been successful in penetrating the Mexican market. For those reasons, Economía did not accept the argument by the exporters that Fortuny's inability to use the Ybarra brand was causing it injury in the sense of preventing Fortuny from resuming operations. ${ }^{\text {}}$ From an economic perspective, the fact that other brands had penetrated the Mexican market fails to address the issue that Fortuny's need to establish a new brand is a new cost that it will have to incur (that it did not have to face before 2002) and thus will 'cause' its supply curve to shift upward (see again Figure 5(a)).

Furthermore, with respect to the issue of the distribution network, the Panel also accepted the Mexican argument that 'Economía noted that Fortuny had indicated that it had access to a distribution network, which it planned to use when it resumed operations'. ${ }^{82}$ From an economic perspective, the Panel failed to address the issue that there needs to be an assessment of how costly it was for Fortuny to develop this new distribution network (a cost to its production that it also did not have to face before 2002). If this was costly, it was therefore also a cause of Fortuny's upward shift of its supply curve (see again Figure 5(a)), resulting in the new equilibrium price and the possibility that it may be at a level sufficiently low for Fortuny to have to shut down production. 


\subsubsection{The combined effects of the EC subsidy and the severance with Ybarra}

In reality, both the elements of Figure 4 (the EC subsidy) and Figure 5 (the domestic cost shock associated with the severance of the relationship with Ybarra) are likely to have been at play in injuring the Mexican industry in this instance. Potentially, the investigating authority could have done more to disentangle empirically the relative importance of the competing explanations for the injury to the domestic industry. For example, if the loss of the Ybarra brand and distribution network were the dominant cause of the injury to the domestic industry, the model in Figure 5 predicts that the equilibrium price of olive oil consumed in Mexico would increase compared to the pre-shock level, holding other factors constant. On the other hand, if the EC subsidy were the dominant cause of the injury to the domestic industry, the model in Figure 5 predicts the equilibrium price of olive oil consumed in Mexico would decrease compared to the pre-shock level. Therefore, without a more empirically based assessment of the relative sizes of the two contributing causes of the injury to Fortuny that would control for other factors, Economía's reasoning (and the Panel's acceptance of this reasoning) is not sufficient to rule out convincingly the importance of other known causes of injury to Mexican industry aside from the subsidy.

To conclude this section, consider again the Grossman and Mavroidis insight that the size of the CVD should be determined so as to restore the industry's conditions of competition to what they would have been in the counterfactual situation of the EC subsidy being absent. In this instance, the subsequent fact that the imposed Mexican CVD did not result in a high enough increase in the equilibrium price to induce the Mexican producer to reenter into the production of olive oil suggests it was not able to overcome the other causes of injury (spending resources on a new distribution network and advertising/marketing to establish a new brand name) to the Mexican producers that caused the upward shift in the domestic supply curve illustrated in Figure 5(a). Indeed, the lack of reentry into this market by the domestic firm following the imposition of an actual countervailing duty provides anecdotal evidence that these 'other' causes of injury that Economía convinced the Panel it had adequately considered, but which it determined were not important, may have actually been quite sizable.

\subsection{Implementation of 'procedural' violations of the SCM and Anti-Dumping Agreements}

The Panel's finding that Mexico acted inconsistently with Article 11.11 of the SCM Agreement by failing to conclude the investigation within 18 months raises the question of how Members that are found to have acted inconsistently with the 'procedural' requirements of the SCM and Anti-Dumping Agreements in their conduct of countervailing-duty and anti-dumping investigations must implement the Panel findings in those cases.

Article 19.1 of the DSU provides that when a measure is found to be inconsistent with a provision of the WTO agreements, the Member concerned is recommended 
to 'bring the measure into conformity' with the relevant legal obligations. Put simply, the Member must fix the problem. But, while it may be simple to fix an improperly calculated anti-dumping or CVD duty rate by recalculating it, how is a Member to fix, post hoc, a problem such as a failure to complete an investigation within the deadline specified in the SCM Agreement? There seem to be only two possibilities - one would be to conclude that the failure led to a fatally flawed measure and, therefore, to terminate the measure; the other would be to redo the investigation completely within the proper time limit. The former might seem an unduly harsh remedy for the implementing Member, the latter would certainly be an unduly severe remedy for the successful complaining Member!

This issue has not arisen clearly in previous Panel proceedings. Given the tendency in trade-remedy disputes for complainants to make a wide variety of claims, the defending Members generally must implement with respect to several claims, including both 'procedural' and 'substantive' claims. In such cases, in implementing with respect to 'substantive' claims (such as the recalculation of a dumping margin), the implementing Member normally 'fixes' the procedural violation by, for example, in the case of an infringement of an exporter's right to comment, allowing the exporter that right in the implementation proceedings. Because the exporting Member is generally more concerned with fixing the substantive violations, which may lead directly to reduced anti-dumping or CVD rates, than with the ephemeral benefits of remedying the procedural violations, this modus operandi is more or less accepted. In proceedings under Article 21.5 of the DSU, moreover, complaining Members have focused on the 'substantive' violations that are more likely to affect the existence of the measure or the amount of the applicable anti-dumping or countervailing duty than the 'procedural' violations, which are perceived as being unlikely to affect either the existence or the amount of the measure.

Similarly, Panels have exercised their right under Article 19.1 of the DSU to make suggestions as to how the defending Member could implement the recommendations only in situations where the Panel has considered the violations of the Anti-Dumping Agreement ${ }^{83}$ to be 'fundamental and pervasive'. ${ }^{84}$ The only violations that Panels have emphasized over others as grounds for suggesting that a measure be terminated are those relating to the initiation of the investigation. ${ }^{85}$

In contrast, there does not appear to have been a case in which the only issues for implementation related to what would normally be considered as 'procedural' claims in which the due-process rights of the exporter or exporting Member were found not to have been properly respected.

83 No Panel has exercised its discretion under Article 19.1 with respect to a countervailing-duty measure challenged under the SCM Agreement.

84 See Panel Report, Mexico-Steel Pipes and Tubes, para. 8.9.

85 Ibid., para. 8.12. See also Panel Report, Guatemala-Cement I, para. 8.6. 
Thus, it remains unclear how a Member must bring a measure that is founded on a 'procedural' violation of WTO rules into compliance. A senior lawyer in the WTO secretariat has suggested that Members may not be required to do anything in these circumstances:

The issue of implementation may be even more problematic where the fault is purely one of process ... Indeed, how does a Member in fact bring an anti-dumping measure 'into conformity' when the flaw is a failure to consult before initiating the investigation? Unless one accepts the proposition that a procedural flaw invalidates a resulting measure and that the whole proceeding must therefore always be redone - an approach that would seem draconian and which would encourage Members to seek out the most minor procedural flaws - it may well be that in such a case no concrete steps are required for implementation. ${ }^{86}$

It is not clear what support there is in the text of the Anti-Dumping or SCM Agreements, or indeed the DSU for this fairly extreme view, which runs counter to the principle of $u b i$ jus, ibi remedium. The only basis for this view would appear to be the pragmatic view that Members, or at least those that frequently use contingent-protection measures, are reluctant to accept that measures would have to be terminated based on what are perceived as technical errors in the investigation leading to the imposition of the measure. It could also be argued that since it is impossible to know how the investigation might have unfolded had the procedural violation not occurred, it is not reasonable to assume that the measure would not have been imposed in the same manner even if all procedural requirements had been respected. ${ }^{87}$

Perhaps there is no single answer to this problem. With respect to some 'procedural' violations, such as the delay in completing the investigation in this case, the question is stark: either the measure must be terminated or there is no remedy at all. With respect to other violations, such as a failure to afford an opportunity to exporters to defend their interests under Article 6.2 of the Anti-Dumping Agreement or Article 12.3 of the SCM Agreement, a defending Member could, in theory, remedy the violation by affording the exporters an opportunity to defend their interests by submitting comments in an implementation proceeding. It would be naïve, however, to assume that an opportunity to submit comments in an implementation proceeding a couple of years after the measure has already been imposed will have the same impact as the same opportunity might have had during the original investigation. With respect to other 'procedural' violations, such as the Panel's finding in this case that Economía acted inconsistently with Article 12.4.1

86 Kreier (2005: 60-61).

87 See Panel Report, Guatemala-Cement I, para. 7.42 ('while it is possible that the investigation would have proceeded in the same manner had Guatemala timely notified Mexico before proceeding to initiate the investigation, we cannot say that the course of the investigation would not have been different'). 
of the SCM Agreement by failing to require nonconfidential summaries of confidential information, it is even more difficult to speculate whether compliance with the obligation initially would have changed the outcome of the initial investigation.

A further complication of this problem arises out of the Panel and Appellate Body rulings in the Mexico-Anti-Dumping Measures on Rice dispute. In that dispute, the Appellate Body upheld the Panel's finding that a determination of injury in an anti-dumping investigation was not based on positive evidence of actual injury where there was a 15 -month gap between the end of the period of investigation and the initiation of the investigation, and a gap of almost three years between the end of the period of investigation and the imposition of final antidumping duties. ${ }^{88}$ This requirement of proximity in time between the period of investigation and the imposition of trade-remedy measures raises the question of whether it is ever possible to 'fix' a flawed trade-remedy measure.

For example, if, in the present case, Mexico had initiated implementation proceedings to bring its olive-oil CVD measure into compliance with the Panel's rulings and recommendations, those proceedings would have been initiated in late 2008 and likely not initiated until early 2009. However, the period of investigation used by Economía was April to December 2000, 2001, and 2002. Thus, an implementation proceeding may have resulted in the imposition of WTO-consistent CVDs (for the first time) in 2009, based on data that would be almost seven years old. This would presumptively be inconsistent with the Appellate Body and Panel rulings in Mexico-Anti-Dumping Measures on Rice. However, it is unlikely that Panels in future Article 21.5 proceedings would take the position that antidumping or CVD measures that are found to be inconsistent with the AntiDumping or SCM Agreements cannot subsequently be brought into compliance in implementation proceedings because the investigation period would be so outdated (arguably, it would be improper for the implementing Member to use a new and updated period of investigation in the implementation proceedings without initiating an entirely new investigation).

As noted, there is little guidance in the jurisprudence to date on what, if anything, is the implementation obligation with respect to 'procedural' rights and obligations under the Anti-Dumping or SCM Agreements. The issue is likely to remain unclear until a Panel is confronted squarely with the question of what an investigating authority must do to implement with respect to purely 'procedural' violations. In the meantime, however, the lack of clarity as to how findings with respect to 'procedural' issues must be implemented may serve to discourage potential complainant Members, especially developing countries with lesser resources, from pursuing these claims in dispute-settlement proceedings. 


\subsection{Other issues in the Panel Report}

The Panel Report raises some other issues that might be more interesting in a different context. For the reasons described below, however, they merit only brief mention here.

\subsubsection{The 'pass-through' issue}

The issue of whether a 'pass-through' analysis is required has been controversial in WTO jurisprudence, especially in the context of the privatization of manufacturers benefiting from the subsidies. In this case, however, the pass-through issue was ultimately not controversial from a legal or economic point of view. As a legal matter, the Panel found that the EC had raised its claims under the wrong provisions of the GATT 1994 and the SCM Agreement (Articles 1 and 14 of the SCM Agreement rather than Article 10 of the SCM Agreement and Article VI:3 of the GATT 1994). It is unclear why the EC proceeded as it $\operatorname{did} .^{89}$ In any event, in its consideration of the EC's claims under Articles 1 and 14, the Panel indicated that even if the obligation to conduct a pass-through analysis in appropriate circumstances could be found in the provisions cited by the EC, the Panel would not have found a pass-through analysis to be necessary in this case. The Panel cited the fact that the olive growers received aid only to the extent that the olives grown were actually converted into olive oil..$^{90}$ In effect, the Panel found that where the subsidy was actually provided on the basis of the finished product that was subject to the investigation and not on the basis of the input product, a pass-through analysis would be redundant. It is hard to disagree with this commonsensical conclusion from either economic or legal standpoints.

\subsubsection{Is a producer that has ceased to produce entitled to seek trade-remedy relief?}

As explained above, the EC made much of its claims that Fortuny could not constitute a 'domestic industry' for the purposes of and entitlement to relief under the CVD laws because it had ceased production. We have no quarrel with how the Panel addressed this issue: as the Panel noted, there are many 'normal' business or commercial situations in which companies may cease production and these should not disqualify such companies from recourse to the trade-remedy laws. In addition, the availability of trade-remedy relief in cases of the material retardation of the establishment of a domestic industry supports, rather than undermines, the notion that relief should be available in cases of material retardation of the $r e$-establishment of a domestic industry. Finally, as the Panel noted, a domestic industry could have ceased production because it was so badly injured by the very

89 See Panel Report, para. 7.145, n.185.

90 Ibid., para. 7.168. 
imports against which it then sought relief: as the Panel stated, to deny such an industry recourse to the trade-remedy laws would be 'absurd' ${ }^{91}$

The more interesting question may be how to identify the point at which a domestic industry that has ceased production is no longer entitled to the relief of the trade-remedy laws: at what point can the patient be said to be beyond resuscitation by means of anti-dumping or CVD duties? In the language of economic analysis, the key question is when the firm's situation converts from being temporarily 'shut down' - a short-run phenomenon in which it decides not to produce in the current period because prices are not high enough to cover its variable costs - to a permanent decision to 'exit' the industry. The Panel did not fully resolve this issue. However, it noted that Fortuny had maintained its olive groves and production facilities and had created a new brand and label and, of course, its business plan. ${ }^{92}$ In the circumstances, the Panel considered that the patient was not beyond resuscitation. A more definitive answer to this question, however, will have to wait for another day.

\subsubsection{Reliance on the domestic producer's business plan as evidence of injury}

As noted above, the Panel exercised judicial economy with respect to the EC's claims under Articles 15.1 and 15.4 of the SCM Agreement that raised the issue of Economía's reliance on Fortuny's business plan in its analysis of the volume and price impact of the subsidized imports on the domestic industry. It would have been interesting to have a more detailed discussion by the Panel of whether, and in what circumstances, evidence of domestic-industry factors, including prices, can be based on such 'non-actual' sources as a business plan. Article 15.1 of the SCM Agreement requires that a determination of injury be based on 'positive evidence' and an 'objective examination' of the impact of the imports.

Generally, the evidence in question would be actual prices and performance of the domestic industry. In cases of material retardation of the establishment of a domestic industry, there would quite likely not be 'actual' evidence of the performance or prices of the domestic industry and the investigating authority would have to rely on projections. Interestingly, in this case, the Panel found that Economía's determination was based on a finding of material injury, not on material retardation. ${ }^{93}$ However, it makes sense also to permit investigating authorities to rely on evidence such as business plans in appropriate situations. In this case, the Panel considered the fact that Fortuny did not actually produce was sufficient grounds to allow Economía to rely on the business plan. However, the Panel did not address the issue of whether investigating authorities were required to approach evidence such as business plans with greater skepticism than ordinary price or financial data. Given the potential for gaming the system in preparing

91 Ibid., para. 7.203.

92 Ibid., para. 7.213.

93 Ibid., para. 7.279. 
such evidence, a degree of caution in approaching such evidence would seem appropriate.

\section{Conclusions}

The Mexico-Olive Oil dispute was neither as complicated nor as controversial as some WTO trade-remedy cases. By the first measure of any judicial decision, the Panel's Report was a success: it was not appealed. By another measure of WTO dispute-settlement proceedings, it was also successful: Mexico implemented the Panel's rulings and recommendations promptly and, from the point of view of the EC, effectively by terminating the measure. Nevertheless, as we hope the above discussion explains, the case illustrates some of the problems that arise in even the less controversial trade-remedy dispute-settlement proceedings. In the respects we highlighted, the Panel's approach to these problems suggests that the review by WTO Panels of trade-remedy measures remains an art in need of more science.

\section{References}

Appellate Body Report, United States - Safeguard Measures on Imports of Fresh, Chilled or Frozen Lamb Meat from New Zealand and Australia, WT/DS177/AB/R, WT/DS178/AB/R, adopted 16 May 2001, DSR 2001 :IX, 4051.

Appellate Body Report, United States - Anti-Dumping Measures on Certain Hot-Rolled Steel Products from Japan, WT/DS184/AB/R, adopted 23 August 2001, DSR 2001:X, 4697.

Appellate Body Report, United States - Countervailing Duty Investigation on Dynamic Random Access Memory Semiconductors (DRAMS) from Korea, WT/DS296/AB/R, adopted 20 July 2005, DSR 2005 :XVI, 8131.

Appellate Body Report, Mexico - Definitive Anti-Dumping Measures on Beef and Rice, Complaint with Respect to Rice, WT/DS295/AB/R, adopted 20 December 2005, DSR 2005 :XXII, 10853.

Appellate Body Report, United States - Investigation of the International Trade Commission in Softwood Lumber from Canada-Recourse to Article 21.5 of the DSU by Canada, WT/DS277/AB/RW, adopted 9 May 2006, and Corr.1, DSR 2006:XI, 4761.

Economía, 'Resolución final de la investigación por subvención de precios sobre las importaciones de aceite de oliva virgen, originarias de la Unión Europea (Comunidad Europea), principalmente del Reino de España y la República Italiana, independientemente del país de procedencia', 1 August 2005, para. 22.89; available at http://www.pymes.gob.mx/upci/paginas/dofsc908.pdf (last accessed 22 October 2009).

Grossman, Gene M. and Petros C. Mavroidis (2003), 'United States - Imposition of Countervailing Duties on Certain Hot-Rolled Lead and Bismuth Carbon Steel Products Originating in the United Kingdom: here today, gone tomorrow? privatization and the injury caused by non-recurring subsidies', in Henrik Horn and Petros C. Mavroidis (eds.), The WTO Case Law of 2001, Cambridge: Cambridge University Press.

Grossman, Gene M. and Petros C. Mavroidis (2005a), 'United States - Countervailing Duties on Certain Corrosion-Resistant Carbon Steel Flat Products from Germany: the sounds of silence', in Henrik Horn and Petros C. Mavroidis (eds.), The WTO Case Law of 2002, Cambridge: Cambridge University Press. 
Grossman, Gene M. and Petros C. Mavroidis (2005b), 'United States-Countervailing Measures Concerning Certain Products from the European Communities: recurring misunderstanding of non-recurring subsidies', in Henrik Horn and Petros C. Mavroidis (eds.), The WTO Case Law of 2002, Cambridge: Cambridge University Press.

Horn, Henrik and Petros C. Mavroidis (2006), United States - Final Determination with Respect to Certain Softwood Lumber from Canada (AB-2003-6, WT/DS257/AB/R), in Henrik Horn and Petros C. Mavroidis (eds.), The WTO Case Law of 2003, Cambridge: Cambridge University Press.

Kreier, Jesse (2005), 'Contingent trade remedies and WTO dispute settlement: some particularities', in Rufus Yerxa and Bruce Wilson (eds.), Key Issues in WTO Dispute Settlement: The First Ten Years, Cambridge: Cambridge University Press.

Panel Report, Guatemala - Anti-Dumping Investigation Regarding Portland Cement from Mexico, WT/ DS60/R, adopted 25 November 1998, as modified by Appellate Body Report WT/DS60/AB/R, DSR 1998:IX, 3797.

Panel Report, United States - Safeguard Measures on Imports of Fresh, Chilled or Frozen Lamb Meat from New Zealand and Australia, WT/DS177/R, WT/DS178/R, adopted 16 May 2001, as modified by Appellate Body Report WT/DS177/AB/R, WT/DS178/AB/R, DSR 2001:IX, 4107.

Panel Report, Mexico - Anti-Dumping Duties on Steel Pipes and Tubes from Guatemala, WT/DS331/R, adopted 24 July 2007.

Panel Report, Mexico-Definitive Countervailing Measures on Olive Oil from the European Communities, WT/DS341/R, adopted 21 October 2008. 